\title{
Ceramic Petrographic Analysis of Sites 41CP71, 41BW2, 41BW5, and 41SM442, Northeast Texas
}

David G. Robinson

Timothy K. Perttula

Heritage Research Center, Stephen F. Austin State University

Follow this and additional works at: https://scholarworks.sfasu.edu/ita

Part of the American Material Culture Commons, Archaeological Anthropology Commons, Environmental Studies Commons, Other American Studies Commons, Other Arts and Humanities Commons, Other History of Art, Architecture, and Archaeology Commons, and the United States History Commons

Tell us how this article helped you.

This Article is brought to you for free and open access by the Center for Regional Heritage Research at SFA ScholarWorks. It has been accepted for inclusion in Index of Texas Archaeology: Open Access Gray Literature from the Lone Star State by an authorized editor of SFA ScholarWorks. For more information, please contact cdsscholarworks@sfasu.edu. 
Ceramic Petrographic Analysis of Sites 41CP71, 41BW2, 41BW5, and 41SM442, Northeast Texas

\section{Creative Commons License}

\section{(c) (1) \&}

This work is licensed under a Creative Commons Attribution-NonCommercial 4.0 International License 


\title{
Ceramic Petrographic Analysis of Sites 41CP71, 41BW2, 41BW5, and 41SM442, Northeast Texas
}

\author{
David G. Robinson and Timothy K. Perttula
}

\section{INTRODUCTION}

A total of 61 ancestral Caddo ceramic sherds from four village sites in Northeast Texas were studied by ceramic petrographic methods in 2014. The sample sherds were excavated from their sites under controlled conditions and were either archived at the Texas Archeological Research Laboratory at The University of Texas at Austin (41BW2), Stephen F. Austin State University (41CP71), or remain in private hands (41SM442). Recently, they were selected for combined petrographic and instrumental neutron activation analysis (INAA), although only the sherds from the Alligator Pond site (41SM442) have actually been submitted and analyzed by INAA at this time (see Trubitt et al. 2014). This combination of approaches is part of a change in Northeast Texas ceramic technological studies termed a second generation by some (Robinson 2014), although such multiple combined approaches have long been advocated and applied in general archaeological literature (Orton et al. 1993:144-148). The approach looks at the geochemical and petrological characteristics of ceramics in tandem to gain a broader and more informative background on the character of ancient pottery. This study is the petrographic branch of the overall approach; the objective here is to gain clues or suggestions on local, community, and regional scales of Caddo ceramic production and distribution. Part of this effort is to attempt to identify localities and types of clay beds used in ceramic manufacture.

\section{Methods}

The petrographic analysis of the Caddo pottery sherds was accomplished by thin section analysis, pioneered in archaeology by Shepard $(1942,1976)$. National Petrographic of Houston, Texas, prepared the thin sections of the ceramic sample. Identification and point counting were conducted on an Olympus stereo petrographic, polarizing light microscope with a rotating stage at the Texas Archeological Research Laboratory (TARL) at The University of Texas at Austin. After the various minerals, rocks, and other discernible bodies in the thin sections were identified with confidence, a point count was made of each thin section. The slide was traversed at approximate $0.5 \mathrm{~mm}$ intervals, and every body falling directly in the center of the field of view was counted; traverses continued until a count of 200 was achieved or the area of the slide was fully covered. The procedure follows the original method of Chayes (1949). The clay body, all solid inclusions and pore spaces, or voids, were included in the counts as they all comprise the pattern of the ceramics. In all mechanically consistent processes such as point counting, rare and unrepresentative (but potentially signal) phenomena may fail to enter the sample. When rare minerals were observed but did not enter the point count, they were entered on the tabulation sheet as 'tr.' for trace. In this way, their presence and contribution were noted without violating the consistency of the point count. The outcome of the point count is a quantified assessment of the collection's ceramic attributes, a body of data amenable to comparisons with other similarly gained data and manipulation by a variety of statistical measures (Table 1). 
Table 1. Ceramic Petrography of Four Prehistoric Sites in Northeast Texas. Notes at bottom of sheet; aplastic inclusions and voids are reported as proportions of a 200 or best count.

\begin{tabular}{|c|c|c|c|c|c|c|c|c|c|c|c|}
\hline & Paste features & & & & & & & & & Quartz & \\
\hline Section & $\begin{array}{l}\text { Paste } \\
\text { Group/variety }\end{array}$ & color ppl & color xpl & Isotropism & $\begin{array}{l}\text { Particle } \\
\text { Diversity } \\
\end{array}$ & $\begin{array}{l}\text { Median particle } \\
\text { size }\end{array}$ & Count & Matrix & Voids & Qtz plutonic & Qtz sheared \\
\hline $41 C P 71-2 A$ & A & golden-brown & dark gray & iso & 7 & c.silt & 122 & 23 & 14 & 2.4 & \\
\hline $41 \mathrm{CP} 71-4 \mathrm{~A}$ & A & red. Greeninsh-gold & dk. Yellowish gray & iso & 8 & fine sand & 200 & 30 & 13 & 10.5 & \\
\hline 41CP71-7A & A & med. Brown & r. brown/dk. Gold & aniso & 8 & c. silt & 200 & 12.5 & 12.5 & 10 & \\
\hline 41CP71-17A & $\mathrm{B}$ & greenish gray & gold and gray & aniso & 9 & c. silt & 200 & 25.5 & 20.5 & 7.5 & 1.5 \\
\hline 41CP71-9A & B & tan-brown & dk. Gold/black & aniso & 12 & fine sand & 200 & 16.5 & 11 & 34.5 & 3.5 \\
\hline $41 \mathrm{CP} 71-8 \mathrm{~A}$ & B var. 1 & greenish-gold & black/grayish tan & aniso & 5 & c. silt & 200 & 24 & 25 & 13.5 & \\
\hline 41CP71-3A & B var. 2 & golden-brown & various & aniso & 9 & fine sand & 200 & 22. & 7 & 40 & 4.5 \\
\hline 41CP71-10A & C & greenish gray & gold to brown & aniso & 9 & c. silt & 200 & 11 & 5.5 & 4.5 & \\
\hline 41CP71-13A & C & grayish brown & grayish brown & aniso (sl.) & 11 & c. silt & 200 & 9.5 & 12.5 & 19 & 6 \\
\hline 41CP71-16A & D & black & black & iso & 8 & fine sand & 200 & 20 & 21.5 & 45.5 & 4.5 \\
\hline 41CP71-6A & D & black & black & iso & 7 & C. silt & 200 & 23 & 20 & 37.5 & 4 \\
\hline 41CP71-14A & E & med. Brown & golden brown & iso & 9 & c. silt & 200 & 12 & 12.5 & 10.5 & 2 \\
\hline 41CP71-15A & E & greenish gray & dk golden brown & iso & 11 & c. silt & 200 & 21 & 5 & 12.5 & 1 \\
\hline $41 C P 71-12 A$ & E var. 1 & black & black & iso & 9 & fine sand & 200 & 16 & 23 & 28.5 & 1.5 \\
\hline $41 C P 71-5 A$ & E var. 2 & It. grayish gold & r. br. To dk r. br. & aniso (sl.) & 12 & c.silt & 200 & 15 & 3 & 34.5 & 1 \\
\hline 41CP71-1A & Evar. 2 & greenish-gold & gold to black & aniso & 10 & fine sand & 187 & 26 & 12.2 & 12.2 & 1.6 \\
\hline 41CP71-11A & F & greenish gray & gold to black & aniso & 12 & c. silt & 200 & 9 & 8 & 12.5 & \\
\hline 41BW2-17A & $G$ & black & black & iso & 9 & fine sand & 200 & 29.5 & 15.5 & 8 & 0.5 \\
\hline 41BW2-18A & $G$ & black & black & iso & 9 & fine sand & 200 & 25 & 29.5 & 1.5 & 0.5 \\
\hline 41BW2-12A & G var. 1 & black & black & iso & 10 & fine sand & 200 & 13 & 16 & 30 & 2.5 \\
\hline 41BW2-3A & $\mathrm{H}$ & dk. Greenish gray & black & iso & 7 & fine sand & 200 & 20 & 20.5 & 3.5 & 0.5 \\
\hline 41BW2-1A & $\mathrm{H}$ & reddish brown & dk. Gray & iso & 11 & c. silt & 200 & 14 & 17 & 3.5 & 1 \\
\hline 41BW2-7A & $\mathrm{H}$ & reddish gray & black & iso & 7 & med. Sand & 200 & 28.5 & 17.5 & & \\
\hline 41BW2-11A & $\mathrm{H}$ & v. dark brown & black & iso & 8 & c. silt & 200 & 14.5 & 16.5 & 4.5 & 1 \\
\hline 41BW2-13A & |H & dk. Reddish brown & black & iso & 6 & c. silt & 200 & 18.5 & 30 & & \\
\hline 41BW2-6A & $\mathrm{H}$ var. 1 & medium brown & gold to black & aniso & 10 & c. silt & 200 & 15 & 12.5 & 1.5 & 0.5 \\
\hline 41BW2-5A & $\mathrm{H}$ var. 1 & reddish brown & gold to black & aniso & 8 & c. silt & 200 & 19 & 20.5 & 8 & 1 \\
\hline 41BW2-8A & $\mathrm{H}$ var. 1 & m. reddish brown & gold to black & aniso & 9 & fine sand & 200 & 22.5 & 20 & 3.5 & 1 \\
\hline 41BW2-21A & $\mathrm{H}$ var. 2 & medium brown & black & iso & 8 & c. silt & 200 & 15.5 & 21.5 & 3.5 & \\
\hline 41BW2-14A & H var. 2 & medium brown & med gold-brown & iso & 8 & c. silt & 200 & 11.5 & 16 & 0.5 & \\
\hline $41 \mathrm{BW} 2-2 \mathrm{~A}$ & . & dk. Brown & dk. Grayish gold & iso & 11 & c. silt & 200 & 12.5 & 8 & 4.5 & \\
\hline 41BW2-4A & J & yellow-brown & gold to gray & aniso & 9 & med. Sand & 200 & 15 & 11.5 & 0.5 & \\
\hline 41BW2-10A & | & dark brown & black & iso & 5 & fine sand & 200 & 17.5 & 17 & | & \\
\hline 41BW5-1A & $\mathrm{J}$ & dk. Gray & black & iso & 8 & fine sand & 200 & 10 & 10 & 1.5 & 0.5 \\
\hline 41BW2-16A & $\mathrm{J}$ var. 1 & medium brown & dk. Reddish brown & iso & 10 & fine sand & 200 & 15 & 8.5 & 11 & \\
\hline 41BW2-15A & $\mathrm{K}$ & dk gray and black & v. dk. Gray & iso & 6 & fine sand & 200 & 19.5 & 24 & 9 & \\
\hline 41BW2-19A & K & It. $\tan /$ gold & gold to reddish brown & aniso & 8 & fine sand & 200 & 12.5 & 15 & 34.5 & 1.5 \\
\hline 41BW2-20A & $K$ & medium brown & gold to reddish brown & aniso & 9 & fine sand & 200 & 20 & 12 & 16.5 & 2.5 \\
\hline 41BW2-9A & $L$ & medium brown & gold to gray & aniso & 12 & fine sand & 200 & 17.5 & 7.5 & 6 & 2 \\
\hline 41SM442-21 & M & yellow-brown & gold to black & aniso & 9 & c. silt & 200 & 12 & 20.5 & 13.5 & 1.5 \\
\hline 41SM442-20 & M & yellow-brown & gold to dk. Brown & aniso & 9 & c. silt & 200 & 21.5 & 15 & 18 & \\
\hline 41SM442-18 & M & med. Yellow-brown & gold to black & aniso & 9 & fine sand & 200 & 26.5 & 12.5 & 12.5 & 1 \\
\hline 41SM442-9 & M & It. tan/brown & brown to gold & aniso & 10 & c. silt & 200 & 18 & 15.5 & 14 & 1.5 \\
\hline 41SM442-8 & M & It. tan/brown & brown to gold & aniso & 10 & c. silt & 200 & 28 & 15.5 & 1.5 & 0.5 \\
\hline 41SM442-13 & M & yellow-brown & gray to gold & aniso & 10 & c. silt & 200 & 10.5 & 20.5 & 5 & \\
\hline 41SM442-2 & M & yellowish tan & gold to black & aniso & 8 & c. silt & 200 & 15.5 & 23 & 1.5 & \\
\hline 41SM442-5 & $\mathrm{N}$ & med. Red-brown & black & iso & 12 & c. silt & 200 & 17.5 & 13 & 15.5 & 2 \\
\hline 41SM442-7 & $\mathrm{N}$ & reddish-black & black & iso & 11 & fine sand & 200 & 13 & 19 & 17.5 & \\
\hline 41SM442-14 & $\mathrm{N}$ & It. tan/red-brown & gold to black & aniso & 11 & fine sand & 200 & 10.5 & 13 & 15.5 & \\
\hline 41SM442-22 & $\mathrm{N}$ & medium brown & black & iso & 11 & c. silt & 200 & 22 & 13 & 3.5 & \\
\hline 41SM442-1 & 0 & black & black & iso & 9 & fine sand & 200 & 6.5 & 30 & 14 & 0.5 \\
\hline 41SM442-10 & 0 & red-brown & black & iso & 12 & c. silt & 200 & 18 & 10.5 & 10.5 & \\
\hline 41SM442-6 & 0 & medium brown & black & iso & 11 & fine sand & 200 & 12.5 & 14 & 12.5 & \\
\hline 41SM442-12 & 0 & med. Red-brown & dk gray brown & iso & 10 & c. silt & 200 & 12 & 8 & 4.5 & 0.5 \\
\hline 41SM442-15 & 0 & reddish-brown & black & iso & 9 & medium sand & 200 & 22 & 18 & 1.5 & \\
\hline 41SM442-11. & 0 & gray brown & black & iso & 13 & fine sand & 200 & 14 & 23 & 11.5 & 1.5 \\
\hline $41 \mathrm{SM} 442-3$ & $\mathrm{P}$ & med. Brown & gold to black & aniso & 10 & fine sand & 200 & 16.5 & 24.5 & 15.5 & 0.5 \\
\hline 41SM442-4 & $P$ & med. Brown & gold to black & aniso & 12 & fine sand & 200 & 12.5 & 10.5 & 33.5 & 2.5 \\
\hline 41SM442-16 & P & reddish brown & var. dk gray & aniso (sl.) & 10 & medium sand & 200 & 15 & 19 & 12.5 & 1 \\
\hline 41SM442-17 & P var. 1 & black & black & iso & 9 & fine sand & 200 & 39 & 17.5 & 25 & 1.5 \\
\hline 41SM442-19 & P var. 1 & brown and black & black & iso & 10 & fine sand & 200 & 27.5 & 20 & 9 & 0.5 \\
\hline
\end{tabular}


Table 1. Ceramic Petrography of Four Prehistoric Sites in Northeast Texas. Notes at bottom of sheet; aplastic inclusions and voids are reported as proportions of a 200 or best count, cont.

\begin{tabular}{|c|c|c|c|c|c|c|c|c|c|c|c|c|}
\hline & & & & & & & & & & & \multicolumn{2}{|l|}{ Igneous } \\
\hline Section & Qtz vein & Qtz schistose & $\begin{array}{l}\text { Qtz silt } \\
\text { fraction }\end{array}$ & Chert & Grog Type & Clay balls & Bone Temper & Shell Temper & $\begin{array}{l}\text { Hematite (all } \\
\text { forms) }\end{array}$ & Rock Types & alkali feldspar & hornblende \\
\hline $41 C P 71-2 A$ & & & 47.5 & & & 2 & & & 14 & & & \\
\hline 41CP71-4A & 0.5 & & 23 & & 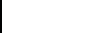 & 10.5 & & & 13.5 & & & \\
\hline 41CP71-7A & & & 55 & & & 4.5 & & & 3 & & & \\
\hline 41CP71-17A & & & 20.5 & tr. & & & & & 21.5 & C- 0.5 & & 0.5 \\
\hline 41CP71-9A & 0.5 & & 3 & 1.5 & & 8 & & & 18 & C-1 & 1.5 & 0.5 \\
\hline 41CP71-8A & & & 9 & & & & & & 27.5 & & & \\
\hline 41CP71-3A & 2 & & 4.5 & & & 2 & & & 13.5 & B- .5 & & \\
\hline 41CP71-10A & & 2.5 & 32.5 & & C-16.5 & & & & 19 & & & \\
\hline 41CP71-13A & & & 27.5 & & A-7.5 & 3.5 & & & 11. & A-1, D-tr. & & \\
\hline 41CP71-16A & 0.5 & & 5 & 2.5 & & & & & 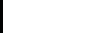 & & & 0.5 \\
\hline 41CP71-6A & 3.5 & & & & & 7.5 & & & 3.5 & & & \\
\hline 41CP71-14A & & & 32.5 & & & 6 & 4 & & 9 & A- -5 & & \\
\hline 41CP71-15A & & & 25.5 & 1.5 & 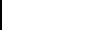 & 2.5 & 12 & to & 16.5 & D-tr. & & \\
\hline 41CP71-12A & 1 & & & 3.5 & & 9 & 9.5 & & 5 & & & \\
\hline 41CP71-5A & 1 & & 7.5 & 2 & 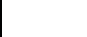 & 2.5 & 10.5 & & 16 & D-tr. & & tr. \\
\hline 41CP71-1A & 0.5 & 1 & 10.7 & & & 7.4 & 23 & & 3.2 & & & \\
\hline 41CP71-11A & & 0.5 & 23 & 3.5 & & 4 & & & 30.5 & A-6, D-tr. & & \\
\hline 41BW2-17A & & & 19 & & & 17.5 & & & 2.5 & & & \\
\hline 41BW2-18A & & & 24 & & . & 13.5 & & & 4 & & & \\
\hline 41BW2-12A & 2.5 & & 23.5 & 1 & & 4 & & & 5.5 & & & 0.5 \\
\hline 41BW2-3A & & & 19 & & & 9 & & & 24.5 & & & \\
\hline 41BW2-1A & & & 37.5 & 3 & 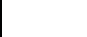 & 5 & & & 12.5 & A-2.5 & & \\
\hline 41BW2-7A & & & 33 & tr. & & 14.5 & & & 6 & & & \\
\hline 41BW2-11A & & & 37.5 & 2 & & 8.5 & & & 13.5 & & & \\
\hline 41BW2-13A & & & 30 & tr. & & T & & & 9.5 & & & \\
\hline 41BW2-6A & & & 26 & & & 20 & & & 15.5 & D-3.5 & & \\
\hline 41BW2-5A & & & 25 & & & 2.5 & & & 20.5 & & & \\
\hline 41BW2-8A & 0.5 & & 26 & & & 9 & & & 13.5 & D-1.5 & & \\
\hline 41BW2-21A & 0.5 & & 32.5 & 0.5 & & 15.5 & & & 7.5 & & & \\
\hline 41BW2-14A & & & 50 & 0.5 & & 3. & & & 11.5 & & & \\
\hline 41BW2-2A & & & 32.5 & 0.5 & $c-5$ & 12.5 & & & 12.5 & A-1, C-2 & & \\
\hline 41BW2-4A & & & 13 & 0.5 & & 5 & & 35.5 & 17.5 & A-tr. & & \\
\hline 41BW2-10A & & & 30 & & & 15.5 & & 15 & 5 & & & \\
\hline 41BW5-1A & & & 19 & & & 7 & & 38 & 12.5 & & & \\
\hline 41BW2-16A & & & 7 & & & 12.5 & & 25 & 15 & 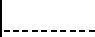 & | & \\
\hline 41BW2-15A & & & 16.5 & & 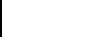 & 14.5 & & & 16.5 & D-tr. & & \\
\hline 41BW2-19A & 1 & & 9 & 1 & 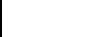 & 6.5 & & & 19 & & & \\
\hline 41BW2-20A & 1. & & 9 & 0.5 & & 17.5 & & & 20.5 & & & \\
\hline 41BW2-9A & & & 25 & 1 & & 5 & & & 16.5 & .... & & \\
\hline 41SM442-21 & 2.5 & & 22.5 & 1 & & 3 & & & 22.5 & C-tr. & & \\
\hline 41SM442-20 & & & 20 & 2 & & 1 & & & 17 & C-. 5 & & \\
\hline 41SM442-18 & & & 32.5 & 1.5 & $A-1$ & 5.5 & & & 6.5 & & & \\
\hline 41SM442-9 & & & 18.5 & 2.5 & & 3.5 & & & 22.5 & C-1.5 & & \\
\hline 41SM442-8 & & & 22.5 & 1.5 & & 3 & & & 18 & A- .5 & & \\
\hline $41 \mathrm{SM} 442-13$ & 1.5 & & 43 & 1 & & 5 & & & 9 & B-1.5 & & \\
\hline 41SM442-2 & & & 41.5 & 1 & & 0.5 & & & 8 & & & \\
\hline 41SM442-5 & 1 & & 23 & 4 & & 2.5 & & & 15 & C-3 & & \\
\hline 41SM442-7 & & & 28 & 1.5 & & 4 & & & 7 & D-1.5 & & \\
\hline 41SM442-14 & & & 15 & 1.5 & & 15.5 & & & 23.5 & B-2 & 0.5 & tr. \\
\hline 41SM442-22 & & & 40 & 5 & A-tr. & 3.5 & & & 6 & & & 1. \\
\hline 41 SM442-1 & & & 12 & & & 11.5 & 15.5 & & 4 & $\mathrm{C}-1$ & & \\
\hline 41SM442-10 & 0.5 & & 27 & 1 & & 2 & 3 & & 15 & $C-1, D-1$ & & \\
\hline 41SM442-6 & & & 12.5 & 2 & & 2 & 27.5 & & 14 & C-1 & & 1 \\
\hline 41SM442-12 & & & 35.5 & 2 & & 7 & 17.5 & & 7 & C-1 & & \\
\hline 41SM442-15 & 0.5 & & 16.5 & & & 12 & 15 & & 6.5 & & & \\
\hline 41SM442-11 & 2 & & 18.5 & 2.5 & & 5 & 4.5 & & 13 & B-3.5 & & 0.5 \\
\hline 41SM442-3 & 0.5 & & 10.5 & 2 & & 7 & & & 15.5 & $\mathrm{C}-2$ & & \\
\hline 41SM442-4 & 3.5 & & 10.5 & 7 & & 2.5 & & & 11.5 & C-4 & 1 & \\
\hline 41SM442-16 & 0.5 & & 10 & 3 & & 17.5 & & & 15 & & & \\
\hline 41SM442-17 & 2 & & 7.5 & & & & & & 5 & & & \\
\hline 41SM442-19 & & & 15.5 & 2 & & 12.5 & & & 10.5 & & & \\
\hline
\end{tabular}


Table 1. Ceramic Petrography of Four Prehistoric Sites in Northeast Texas. Notes at bottom of sheet; aplastic inclusions and voids are reported as proportions of a 200 or best count, cont.

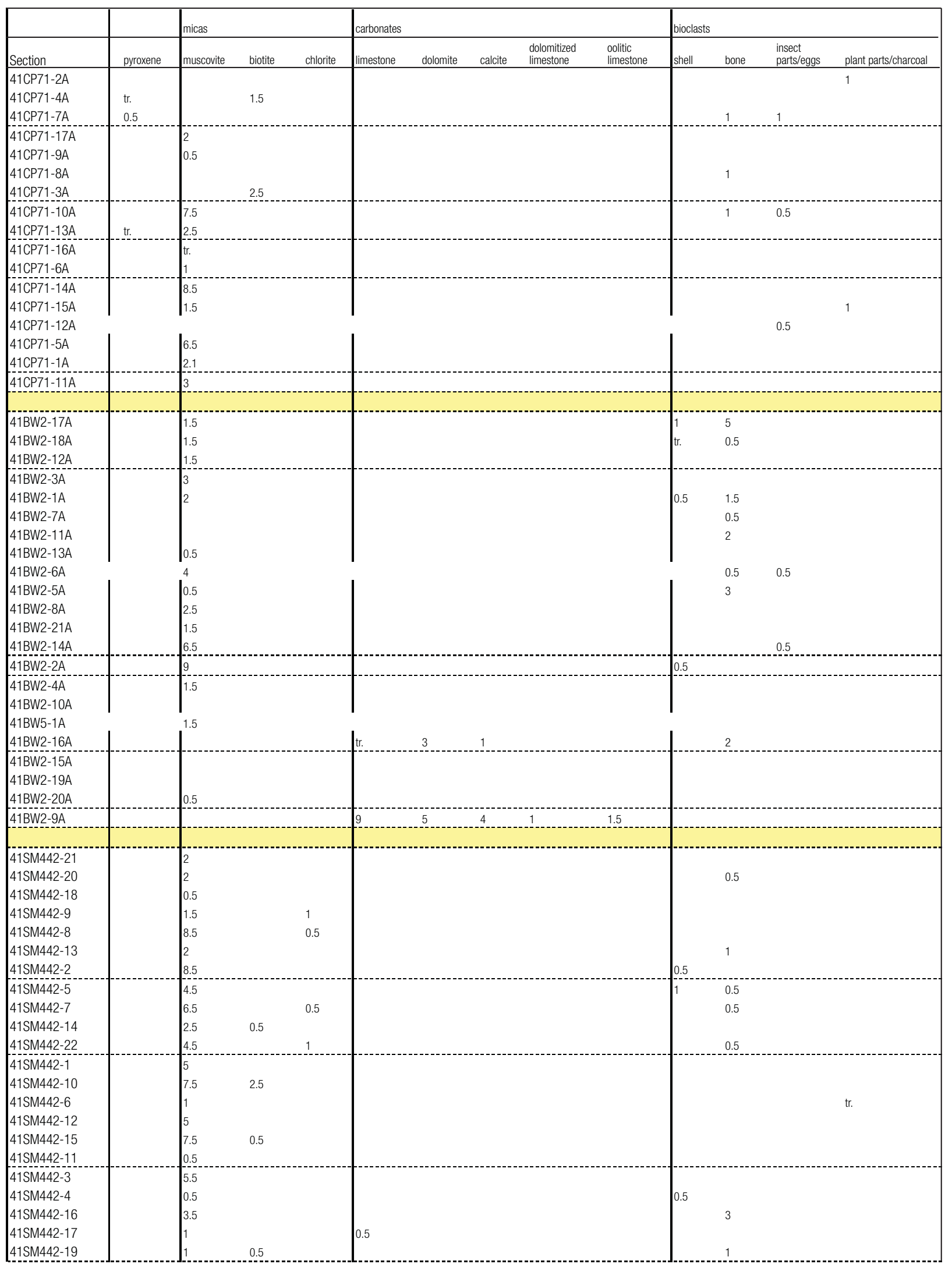




\section{Analysis methods}

\section{Paste groups and varieties}

The principal analytical method applied here is the determination of paste groups and their varieties. The method is evaluative and applies carefully informed judgment; and it follows the approach used in the region in many petrographic studies (Porter 1971; Reese-Taylor 1993, 1994; Robinson 2012; Robinson et al. 2012; Skokan-Switek 1997).

The identification and definition of the paste groups takes a hierarchical approach in first grouping similar sections on the basis of observed paste/matrix characteristics, incorporating color, isotropy, apparent mixing, and void patterns. The second major trait is the tempering agent of the clay paste. Temper is defined for this study as any solid material added to the paste to resist thermal shock. Agents such as bone, shell, and grog are readily determined, but others such as quartz are determined by their size and shape characteristics relative to other aplastic inclusions within the thin section. Also, identification of such minerals as tempers is made on bodies observed at very fine sand (Wentworth) sizes and larger. Clay balls and hematite, sizable and common throughout the sample, are materials generally too soft to serve as buffers to thermal shock. Rock fragments are of incidental but potentially informative occurrence in the sections.

Minor minerals contribute to paste groups as telltales of different sources and cultural localities. As such, they may be determiners of paste group varieties, or in rare but strong relationships, insistent indicators of different pastes entirely. Their presence in clay pastes may have naturally resident or culturally-added origins.

Varieties are defined by notable variations from the principal paste group in matrix traits, tempers, minor minerals, and other aplastic inclusions. Such variations may imply natural differences within clay sources or fluctuations in the addition of materials batch-to-batch in ceramic manufacturing. They may also stem from variations in the resident silt-sized fraction in the clay deposits. The process of distinguishing varieties within a paste group in this way is more judgmental than is the case in identifying the overall major paste group.

Particle diversity is another broad measure of the aplastic inclusions in the ceramic paste. The measure is the sum of all the identifiable kinds of bodies in a section, minus the voids. The matrix is counted as a body. The measure may suggest the degree of mixing of materials or the internal consistency of paste groups. In the study collection as a whole, particle diversity ranged from 5 to 13 .

\section{Analytic issues}

\section{Voids}

Voids have a complex relationship to porosity, permeability, and ceramic texture. Their structure and patterns vary widely with paste composition, preparation, and firing sequences. In general, voids increase in firings up to $800^{\circ} \mathrm{C}$ with the release of absorbed water, and reduce in volume and size relatively rapidly with continuing temperature increase (Rice 1987:351). It should be noted that $800^{\circ} \mathrm{C}$ is well above the estimated maximum firing temperatures of ancestral Caddo ceramics. Voids solidify and assume final shapes upon cooling. In some patterns they show outlining of solid particles, the result probably of pulling away from the particle as the particle, matrix, and any gas in the void start to cool. Patterns in the thin sections may show gross similarities and differences in the paste groups. 


\section{Quartz}

Different forms of quartz have differing forms of petrogenesis. This study observes to the extent possible the different forms of quartz that have varying identifiable rock origins. The method is a change from prior Northeast Texas petrographic studies; many of them have made the simple distinction between monocrystalline and polycrystalline quartz. This simplification merges forms that may have had vastly different petrogenetic sources. Such sources may in turn provide clues to clay resource localities and underlying geologic formations.

Several quartz classifications exist. This study applies one synthesized by Folk (1980:69-72) that retains sensitivity to petrogenesis. The units of the classification are:

- Common or plutonic - formed in granite batholiths or granite gneisses, this is the most common quartz form at the earth's surface. Grain shapes are irregular, and usually they are monocrystalline, with scattered interior air bubbles, or vacuoles.

- Volcanic - formed usually from the erosion of large-grained igneous rocks, the grains commonly show the hexagonal crystallographic system of quartz, or in other words, they are euhedral. They generally lack air bubbles or erosion pitting. This is a relatively rare type.

- Vein - derived from pegmatites, hydrothermal veins, and occasionally sedimentary vein fillings, vein quartz usually has a zoned appearance from bands of vacuoles within the grain, or from stresses that may render rare examples semi-composite. Appearance is usually rounded, and grains may be relatively large.

- Recrystallized metamorphic - formed by recrystallization under strain, the form is found with companion grains, giving it its composite nature. Small interior grains of micas, feldspar, and other minerals are common.

- Schistose - formed within schists as they form, they often have elongated or platy grain shapes and companion micas dispersed among the grains. The form is abundant but may be hard to identify after erosion from the parent schist.

- Sheared (Stretched Metamorphic Quartz) — formed when a quartz-bearing formation is sheared under metamorphic conditions and recrystallization does not occur. Patterns of grains may be sub-parallel but of uneven shapes, and their boundaries may be crenulated, sutured, or finely granulated. Small inclusions and vacuoles are abundant, and the form is common (Folk 1980:69-72).

Chert is a rock formed entirely of quartz, defined as chemically precipitated cavity fills in numerous environments. It is classed on this study's counting sheets as a member of the quartz family. For those preferring the simplified quartz division, the counts of these defined quartz types can be recombined into the dualistic schemes of earlier studies in the following way. Plutonic, volcanic, and vein quartz types are monocrystalline; while recrystallized metamorphic, schistose, and sheared types are polycrystalline.

For analytical purposes, these forms of quartz are thought perhaps to serve as telltales of particular geologic formations. In the collection, the varying types commonly co-occur in varying proportions and not singly or to the exclusion of other types.

\section{Silt}

Almost all clay beds contain a silt-sized fraction of particles in varying proportions. These proportions are commonly reflected in ceramic sherds because the silt fraction is difficult to remove completely in ceramic manufacture. Under the microscope, the internal mineralogy of the silt fraction hampers determination other than to rotate the stage and observe extinction, common to many silt-forming minerals, especially quartz. 
The difficulty in identifying other silty minerals extended to this study. The silt fraction appeared to be entirely angular, very angular, and sub-angular quartz without expectable companions such as feldspar and other residual minerals. These silts are recorded as silt quartz in this study.

This limitation in turn rendered difficult the use of sand classifications (arkosic, subarkosic, arenic, etc.) and maturity indexes (immature, mature, super-mature, etc.) for characterizing the silt and sand fractions throughout the collection. Such sedimentological tools may prove to be somewhat less than useful in ceramics; however, more finely focused studies directed solely toward silt characterization in pottery may eventually prove rewarding.

\section{Rock Fragments}

A rock, defined for purposes of mineralogy, is any item formed of clasts or containing clastic material. Clasts may be almost anything, and they and their study are tools in the field of petrology. Rocks are treated apart from minerals in this study, but they may indicate source localities and clay petrogenesis. In ceramic sherds, their petrological determination is problematic due to erosion and size reduction in preparing clay pastes. Four types of rock fragments of unverified petrology were identified in this thin section collection, and they are classified descriptively here. The exception to this procedure is the reporting of limestone and dolomite, both of which are readily identified as such in even very small particles.

\section{Rock A}

This rock was found in fine sand and medium sand sizes of rounded, elongate, and irregular bodies. The particles are of medium brown or olive tones, low relief, and non-pleoichroic. They are anisotropic, with gold to dark brown or black changes and undulose or wavy fibrous extinction. The possibility exists that the particles might be glauconite, but the characteristic bean shape was not observed in the collection.

\section{Rock B}

A few fine sand-sized particles had pronounced right-angle cleavage and a slight brown to green pleoichroic scheme. The particles have small apparent quartz phenocrysts inside them, and little other information to distinguish them petrologically.

\section{Rock C}

These particles were medium sand-sized and sub-angular bodies, light pinkish-tan with red and black fine silty specks on the surface in plane polarized light (ppl). In cross-polarized light (xpl), the particles were isotropic, their matrixes black, and the specks disappeared. Instead, the light showed interior masses of unoriented silt quartz clasts. In some optical orientations the rock particles in ppl showed a fine wavy parallel fracture pattern. This rock is likely a siltstone.

\section{Rock D}

The rock fragments may actually be classed as an iron opaque, as they are black in ppl and xpl. The interiors frequently have a void pattern resembling a right angle grid. The overall look of the particles is that they are baked and brittle, and many specimens seem to have many fractured areas on them, apparently pulled out in the section-grinding process. Silt-sized quartz particles lie within them in similar fashion to those in coarse sand-sized hematite masses. A reflected light test of the clearest specimens was consistent with the iron-titanium mineral ilmenite, iron titanium oxide $\left(\mathrm{FeO} \mathrm{TiO}_{2}\right)$. The determination was made late in the analysis, and the mineral was left in consideration as a rock fragment, although technically it is a mineral with a few interior quartz clasts. 
Ilmenite as a mineral is often found with magnetite, an iron ore. It is not concentrated in East Texas in commercially exploitable amounts, but it is found in minor scattered deposits in various Cenozoic formations, notably the Simsboro, Carrizo, Queen City, Sparta, Jackson, and Catahoula formations (Shelby and Fisher 1965:200). The Queen City Sand is the most significant ilmenite-bearing formation for the purposes of this study. The mineral/rock fragment may be a telltale sign of local and regional resource localities.

\section{Bioclasts}

Bioclasts are modern or fossil animal or plant parts in a rock, mineral, or ceramic thin section. They are most common as fossil marine organisms in carbonates. Modern organic materials in sedimentary deposits include plant parts, roots, worm casts, invertebrate egg cases, and snail and mussel shell fragments. Charcoal is technically a bioclast and may be introduced into ceramic pastes by natural or cultural means. Brush and forest fires may leave charcoal in deposits, and village cooking and warming fires may distribute charcoal into clay materials incidentally; deliberate use of charcoal as a tempering agent is unlikely, at least in Northeast Texas.

Bioclastic shell, either snail or bivalve, may appear in deposits as eroded pieces of varying sizes and often rounded or sub-rounded. As a hypothesis, bioclastic shell in clay deposits may be more common in alluvial clay deposits where they may be relatively fresh, their presence renewed by continuing fluvial action. Residual deposits by contrast may have relatively little bioclastic shell by reason of a lack of sources (aquatic habitats) for the material and greater available time for the erosion and decomposition of the shell resident in the deposit. For the purposes of this study, bioclastic shell is considered a telltale indication of probable alluvial clay sources versus residual, terrigenous clay beds.

\section{RESULTS}

\section{Paste Groups and Varieties}

\section{Shelby Mound Site (41CP71)}

The Shelby Mound site is one of the premier sites in a Late Caddo Titus phase (ca. A.D. 1430-1680) political community centered in the Greasy Creek basin and neighboring Big Cypress Creek basin in East Texas. The site is on Greasy Creek, the social and political center of a Greasy Creek political community, and stretches for several hundred meters along Greasy Creek and a small tributary, with an earthen mound at the northern end of the village and a large cemetery ( $>100$ interments) at its southern end. Domestic village areas are between the mound and the cemetery and cover at least 10-15 acres (Perttula and Nelson 2004). The Titus phase earthen mound covered a burned structure at the base of the mound, and a second structure had been built that stood on the mound itself, and was then burned and capped with a final sandy fill intermixed with midden deposits. The arrangement of mound, domestic areas, and planned cemetery here is essentially duplicated at other important Titus phase communities in the Big Cypress Creek basin, although the village areas and the size of the cemetery at the Shelby Mound site are considerably larger than are most of the others (Perttula 2012).

The 17 sherds submitted for petrographic analysis from the Shelby Mound site are from excavations in the mound; they are from both fine wares and utility wares (Table 2). The upper mound levels-levels 1-5-are characterized by several ceramic types indicative of the late Titus phase, dating from ca. A.D. 1550-1680. This includes sherds from Cass Appliqued, Hodges Engraved, Keno Trailed, Taylor Engraved, and Ripley Engraved, var. McKinney vessels, especially the latter. This suggests that the uppermost mound fill came from sediments and midden deposits gathered from the adjoining village areas, which were also occupied at this time. The lower mound deposits, levels 6-11, appear to be associated with special purpose house construction/destruction (by burning) and several levels of mound fill zones that took place in the 15th century, during the early Titus phase, from ca. A.D. 1430-1550 (Perttula 2014). 
Table 2. Descriptions of the sherds submitted for petrographic analysis from the Shelby Mound site (41CP71).

\begin{tabular}{|c|c|c|c|}
\hline Sherd No. & Description & Provenience & $\begin{array}{l}\text { Figure } \\
\text { Ref. } \\
\text { (Perttula } \\
2014)\end{array}$ \\
\hline 41CP71-1A & Red-slipped rim & Sq. C, lv. 2 & $17 \mathrm{~b}$ \\
\hline $41 \mathrm{CP} 71-2 \mathrm{~A}$ & cf. Taylor Engraved & Sq. A, lv. 4 & $14 \mathrm{f}$ \\
\hline 41CP71-3A & Taylor Engraved & Sq. D, lv. 2 & $15 \mathrm{a}$ \\
\hline 41CP71-4A & $\begin{array}{l}\text { Bottle sherd with } \\
\text { engraved SZ el. }\end{array}$ & Sq. D, lv. 6 & $16 \mathrm{e}$ \\
\hline $41 \mathrm{CP} 71-5 \mathrm{~A}$ & $\begin{array}{l}\text { Ripley Engraved, var. } \\
\text { McKinney }\end{array}$ & Sq. D, lv. 2 & $11 \mathrm{a}$ \\
\hline 41CP71-6A & $\begin{array}{l}\text { Ripley Engraved with } \\
\text { SZ element }\end{array}$ & Sq. D, lv. 8 & $11 \mathrm{~d}$ \\
\hline 41CP71-7A & Bullard Brushed rim & Sq. D, lv. 8 & $3 a$ \\
\hline 41CP71-8A & Keno Trailed bowl & Sq. D, lv. 3 & $18 \mathrm{~b}$ \\
\hline 41CP71-9A & $\begin{array}{l}\text { Horizontal engraved } \\
\text { and red-slipped compound } \\
\text { bowl }\end{array}$ & Sq. D, lv. 8 & $12 \mathrm{e}$ \\
\hline 41CP71-10A & $\begin{array}{l}\text { Ripley Engraved, var. } \\
\text { Carpenter }\end{array}$ & Sq. A, lv. 9/10 & $12 \mathrm{~b}$ \\
\hline 41CP71-11A & $\begin{array}{l}\text { Brushed-punctated body } \\
\text { sherd }\end{array}$ & Sq. C, lv. 5 & $5 e$ \\
\hline 41CP71-12A & $\begin{array}{l}\text { Horizontal engraved with } \\
\text { tick marks and punctates } \\
\text { at the lip }\end{array}$ & Sq. D, lv. 2 & $13 \mathrm{a}$ \\
\hline 41CP71-13A & Rim punctated jar & Sq. D., lv. 5 & $10 \mathrm{~b}$ \\
\hline 41CP71-14A & $\begin{array}{l}\text { Harleton Appliqued } \\
\text { body sherd }\end{array}$ & Sq. C, lv. 8 & $4 a$ \\
\hline 41CP71-15A & Maydelle Incised rim & Sq. D, lv. 2 & $6 c$ \\
\hline 41CP71-16A & Karnack Brushed-Incised & Sq. C, lv. 8 & $7 \mathrm{c}$ \\
\hline 41CP71-17A & $\begin{array}{l}\text { Harleton Appliqued body } \\
\text { sherd }\end{array}$ & Sq. D, lv. 5 & $2 \mathrm{c}$ \\
\hline
\end{tabular}

\section{Paste Group A}

$41 \mathrm{CP} 71-2 \mathrm{~A}$

$41 \mathrm{CP} 71-4 \mathrm{~A}$

41CP71-7A

Paste Group A is formed of light, dense silty matrixes with some quartz temper. Minor minerals are hematite in moderate to minor amounts and trace amounts of igneous pyroxene. Two sections, 41CP71-2A and 41CP71-7A, have bioclasts in their matrixes, including insect egg cases; seemingly uncharred plant parts; and small, incidental particles of bone. This paste group has no variants.

41CP71-2A. The section has a golden brown matrix, dark gray in xpl. The matrix is silty but is dense in spite of the silt and a few unoriented voids. Hematite in various sizes and forms is the dominant solid material in the matrix other than the silt. A few particles of quartz larger than silt-sized were probably in- 
sufficient to temper the ceramic; and the material may have remained untempered. An unidentified material, possibly sericite, a derived form of mica, was seen in the section, a few times being partially surrounding hematite bodies. The material was not observed elsewhere in the collection. One coarse silt-sized bioclast was observed. It appeared to be an uncharred plant part. Particle Diversity 7.

41CP71-4A. The reddish-, greenish-gold matrix is very dense and isotropic; and quartz in proportions over 10 percent were sufficient as temper, apart from any effects of the resident silt in the firing. Hematite and clay balls are abundant. An unknown silt-sized spicule (probably a form of biotite) and a trace of pyroxene are the minor minerals. Particle Diversity 8.

41CP71-7A. The dark brown matrix is very dense and exceptionally silty. Larger quartz particles in proportions of 10 percent may have been sufficient to temper the paste, and hematite, clay balls, and pyroxene ( 0.5 percent) comprise the minor minerals. Bioclasts in the form of an insect egg case and two silt-sized, rounded pieces of bone were also observed in the thin section. Particle Diversity 8 .

\section{Paste Group B}

41CP71-9A

41CP71-17A

41CP71-8A, var. 1

41CP71-3A, var. 2

Paste Group B is defined by light (tan-brown and greenish-gold) non-silty but dense matrixes (all anisotropic) with long, sometimes parallel strip voids. Hematite is abundant throughout the paste group, and quartz in various forms is the likely temper. The minor minerals include a suite of igneous minerals, except in the varieties. They are distinguished by the lack of volcanics. Two rock fragment types are also found in the group. The paste group is internally consistent and may have come from a residual source bed with generous amounts of hematite. The virtual lack (two incidental pieces of bone in 41CP71-8A) of bioclasts supports this inference, but more evidence would be needed for confirmation.

41CP71-9A. The matrix is tan-brown in ppl, gold to dark gray in xpl, anisotropic, and very dense, with many long strip voids. Hematite is abundant, but quartz in several forms is the dominant particle and obvious temper. Clay balls occur in minor proportions ( 8 percent), and minor minerals include alkali feldspar, muscovite, and hornblende. Two particles of Rock Fragment $\mathrm{C}$ were also observed. Particle Diversity 12

41CP71-17A. The matrix is greenish-gray and anisotropic. Voids are abundant small strips and ovals, and they surround, or outline, many of the solid particles. Hematite is abundant, and it is the dominant particle. Silt is in the highest proportions of any section in the paste group. Plutonic and sheared quartz are the companion quartz temper types. Minor minerals are muscovite, hornblende, and chert. Rock Fragment C was also observed in the section. Particle Diversity 9.

41CP71-8A, variant 1 . The matrix is greenish-gold, slightly anisotropic, dense, but with numerous strip voids. Hematite is the most abundant mineral in the matrix, but moderate plutonic quartz is the tempering agent. Two very small slivers of bone were observed; these are likely incidental inclusions. The section has very low particle diversity and a pronounced lack of minor minerals. Particle Diversity 5.

41CP71-3A, variant 2. The matrix is golden-brown, anisotropic, and very dense with comparatively low proportions of unoriented, irregular voids that do not surround the solid particles. Plutonic quartz temper is the most abundant mineral in the section, followed by hematite. Sheared and vein quartz were also observed in minor proportions. Minor minerals were clay balls, biotite, and a small proportion of silt-sized quartz. One piece of Rock Fragment B was observed. Particle Diversity 9. 


\section{Paste Group C}

41CP71-10A

41CP71-13A

Paste Group C is a light greenish-gray and brown dense silty matrix with few irregular and oval voids. Both examples of the group are clearly tempered with crushed sherd material, or grog, which is distinguished from the clay balls in the matrix by greater angularity and by projecting above the edge or appearing to have been pushed down below the edge in the finishing process. Either situation shows that the grog was harder (fired) than the surrounding matrix during manufacture. In contrast, clay balls that intersect the edge are planed off in the surface finishing process. This shows that their material was soft in the matrix before firing. The paste group also has quartz temper and plentiful hematite. Minor minerals are muscovite, pyroxene, and Rock A. Only 41CP71-10A has bioclasts in the form of a multiple chambered insect egg case and two small splinters of bone. Section 41CP71-13A lacks bioclasts of any kind.

41CP71-10A. The matrix is greenish-gray, anisotropic, with few small rounded voids. The matrix resident silt is the dominant particle, followed by hematite and grog. Other forms of quartz are in proportions sufficient to serve tempering functions. Minor minerals are muscovite and the bioclasts mentioned above. Particle Diversity 9.

41CP71-13A. The matrix is grayish-brown, slightly anisotropic, with strip-like voids in oval and other shapes. The voids outline some of the solid particles. The silt in the matrix is the dominant particle in the section, followed by quartz temper, hematite, and grog. Clay balls are in minor proportion, and the minor minerals are four particles of muscovite and a trace of pyroxene. Two rounded pieces of Rock A were also observed. Particle Diversity 10.

\section{Paste Group D}

41CP71-16A

41CP71-6A

This paste group is formed of two sherds having black matrixes under parallel and crossed polars, relatively little silt, quartz temper, and few minor minerals. The group has no varieties, and relatively low particle diversity ( 8 and 7 , respectively).

41CP71-16A. The sherd has black isotropic paste, quartz temper, and thin, unoriented voids. The minor minerals are muscovite and one observed small piece of hornblende. Particle Diversity 8.

41CP71-6A. The sherd has dense, black isotropic paste, quartz temper, and oriented voids in thin strips. The sherd is a close companion to 41CP71-16A with the exception of the void pattern and a small proportion of clay balls. The minor mineral is muscovite. Particle Diversity 7.

\section{Paste Group $E$}

41CP71-14A

41CP71-15A

41CP71-12A var. 1

41CP71-5A var. 2

41CP71-1A var. 2

Paste Group E has light dense paste, low silt, and bone temper. The group also has plentiful angular quartz and minor minerals including much hematite and minor and trace amounts of muscovite and hornblende. 
Bioclasts in the form of insect egg cases and charcoal were observed in 41CP71-15A and 41CP71-12A.

41CP71-14A. The sherd is typical in having a light but dense isotropic paste medium brown in ppl and golden brown in xpl with much silt, quartz, and a low but significant amount of bone temper. The section also has clay balls, hematite masses, muscovite, and at least one particle of Rock A. Particle Diversity 9.

41CP71-15A. The section has a light dense matrix with a low proportion of voids, isotropic, and greenish-gray in ppl and dark golden brown in xpl. The matrix has much silt and a relatively high proportion of bone temper. Hematite is abundant, and muscovite is rare. The section has bioclastic charcoal and a trace of Rock D. Particle Diversity 11.

41CP71-12A var. 1. The section varies from what is otherwise typical of Paste Group E in having a black isotropic paste in both lights, but otherwise has a significant amount of bone temper and possibly tempering forms of quartz. The section also varies in having very little silt-sized quartz in the section. It contains small amounts of clay balls and hematite and one bioclastic mass of insect egg cases. This section compares closely with Paste Group M at the Hickory Hill site (41CP408) (Robinson et al. 2012). Particle Diversity 9.

41CP71-5A var. 2. This variant has greenish and grayish dense matrix and is anisotropic. The section has a high proportion of bone temper and likely quartz temper as well, with a small amount of silt. Minor minerals are hematite, muscovite, clay balls, a trace of hornblende and a trace of Rock D. This section compares closely with 41CP71-1A and Paste Group L at the Hickory Hill site (Robinson et al. 2012). Particle Diversity 12.

41CP71-1A var. 2. The section has a greenish- and grayish-gold dense matrix, anisotropic, with copious bone temper, significant amounts of quartz temper, and low amounts of silt. Minor minerals are clay balls, hematite, and muscovite. The section compares closely with 41CP71-5A and Paste Group L at the Hickory Hill site (Robinson et al. 2012). Particle Diversity 10.

\section{Paste Group F}

41CP71-11A

The paste group is an outlier, with strong variances from the other Shelby Mound site (41CP71) paste groups. It has a light, dense, silty matrix. The section is anisotropic, greenish-gray in ppl and gold to black in xpl. Voids are unoriented strips that do not outline solid particles. The most common aplastic inclusion other than silt is hematite, followed by plutonic quartz. Rock $\mathrm{A}$ is also a significant contributor to the matrix. Its differences from the other site ceramic sample and regional comparative samples suggest a non-local origin for the sherd, which is from a brushed-punctated utility ware jar (see Table 1).

41CP71-11A. The only member of the paste group, the section has abundant iron in the form of the masses of hematite. It also has iron streaks formed apparently by iron from the hematite masses flowing into the long strip-like voids in the section. The effective look of the section is one of intensive iron enrichment of the sherd and the original ceramic vessel. The section also has a significant proportion ( 6 percent) of Rock A fragments (an unidentified rock) and a trace of Rock D. Particle Diversity 12.

\section{Eli Moores (41BW2) and Roseborough Lake (41BW5) Sites}

The Eli Moores site (41BW2) is an important ancestral Caddo mound center and habitation site on the Red River in the East Texas Pineywoods, likely part of the Nasoni Caddo village visited by the Teran de los Rios entrada in 1691. The site may have been the residence of the Caddi of the Nasoni Caddo when it was visited by the French and Spanish, and the Xinesi lived in a temple on the platform mound at the nearby 
Hatchel site (41BW3). The site was investigated by the University of Texas (UT) in 1932 (Jackson 1932; Good 1977; Gilmore 1991; Perttula 2015), and in one of the mounds and in associated midden deposits, the remains of Caddo structures, midden deposits, features, eight burials (with nine individuals), and a large ceramic and lithic assemblage were recovered, along with well-preserved plant and faunal remains.

The 21 sherds analyzed by petrographic methods from the Eli Moores site are from the 1932 UT excavations (Table 3). They are a mix of sherds from both fine ware and utility ware vessels.

Table 3. Sherds from the Eli Moores site selected for petrographic analysis.

\begin{tabular}{lll}
\hline $\begin{array}{l}\text { Sample } \\
\text { No. }\end{array}$ & Lot No. & Description \\
\hline BW2-1A & No \# & Barkman Engraved body sherd \\
BW2-2A & 1209 & Barkman Engraved rim sherd \\
BW2-3A & 715 & Keno Trailed bottle body sherd \\
BW2-4A & 109 & parallel brushed body sherd, shell-tempered \\
BW2-5A & 81 & parallel brushed body sherd \\
BW2-6A & 1098 & parallel brushed-tool punctated rows through the brushing \\
BW2-7A & 1522 & hatched trailed zone body sherd \\
BW2-8A & 1533 & Foster Trailed Incised body sherd \\
BW2-9A & 524 & interior/exterior red-slipped body sherd \\
BW2-10A & 4067 & Simms Engraved lower rim sherd \\
BW2-11A & 1284 & Barkman Engraved lower rim sherd \\
BW2-12A & No \# & cf. Hatchel Engraved bottle sherd \\
BW2-13A & 1094 & Fingernail punctated rim sherd \\
BW2-14A & 718 & Diagonal incised and lip notched rim sherd \\
BW2-15A & 4216 & Barkman Engraved rim sherd \\
BW2-16A & 4129 & Simms Engraved rim sherd \\
BW2-17A & 4038 & cf. Belcher Engraved lower rim sherd \\
BW2-18A & 4146 & Simms Engraved rim sherd, hubcap style \\
BW2-19A & 3259 & McKinney Plain body sherd (with appliqued ridge) \\
BW2-20A & 1363 & Foster Trailed Incised body sherd \\
BW2-21A & 1056 & Belcher Ridged body sherd \\
\hline
\end{tabular}

The one sherd (41BW5-1A) submitted for petrographic analysis from the Roseborough Lake site (41BW5) is a Natchitoches Engraved sherd from the Joe W. Smith collection at the TARL. The collection appears to have been given by Mr. Smith to A. T. Jackson in the early 1930s, around the time of the UT excavations at the Eli Moores site (41BW2). The Roseborough Lake site is a large historic Caddo village occupied from the $17^{\text {th }}$ century until the late $18^{\text {th }}$ century, with habitation features and cemeteries (Miroir et al. 1973; Gilmore 1986); it is only a short distance west of the Eli Moores site along the Red River. It also is the location of a Nassonite post established by the French in the 1720s, known by the Spanish as San Luis de Cadohadacho.

The thin sections of the Eli Moores (41BW2) and Roseborough Lake (41BW5) sites were analyzed together, given the proximity of the sites to each other. It was thought that their samples may have significant similarities, and indeed the single section from the Roseborough Lake site entered neatly into Paste Group J defined in the Eli Moores site thin sections (see below). 


\section{Paste Group $G$}

41BW2-17A

41BW2-18A

41BW2-12A, var. 1

The paste group is a very dark isotropic, silty matrix, tempered by quartz and having unoriented and irregular voids. The variant section, 41BW2-12A, compares closely with Paste Group D from the Shelby Mound site (41CP71) in having high proportions of plutonic quartz temper. All the pastes in the two groups are notable for dark isotropic pastes, but Paste Group G has much more silt. Both groups lack telltale rock types.

41BW2-17A. The section has a dense, black, silty isotropic paste, tempered with quartz. Minor minerals are hematite, muscovite, and a significant proportion of clay balls. The section is also notable for having a small fraction of bioclastic bone and shell. Particle Diversity 9.

41BW2-18A. The section has a dense, black, silty matrix and quartz temper in a small proportion. Minor minerals are muscovite, hematite, and clay balls. Like 41BW2-17A, the section has both bone and shell bioclasts. Altogether, the two sections are closely similar. Particle Diversity 9.

41BW2-12A. var. 1. The section has the group's black, isotropic, silty paste, but varies from it in having higher amounts of quartz temper. This trait gives it significant similarities to Paste Group D at the Shelby Mound site (41CP71). Minor minerals are muscovite, hematite, hornblende, and clay balls. The section lacks observed bioclasts. Particle Diversity 10.

\section{Paste Group H}

41BW2-3A

41BW2-1A

41BW2-7A

41BW2-11A

41BW2-13A

41BW2-6A var. 1

41BW2-5A var. 1

41BW2-8A var. 1

41BW2-21A var. 2

41BW2-14A var. 2

This is the largest paste group in the collection from the Eli Moores site, with 10 section members. It also has two varieties. Pastes in the group have a range of colors with a central tendency toward reds and browns. This may have been accentuated with the incorporation of clay balls of varying colors and composition. The other major trait of the group is its prevailing siltiness. Quartz is the only candidate for a tempering agent, but the amounts of quartz are very low, suggesting that the original pastes may have been successfully fired without an intentional temper. The paste group has a notable sprinkling of bone bioclasts, but only a single observed shell bioclast (in 41BW2-1A). Paste Group H may be the typical or modal ceramic fabric at the Eli Moores site (41BW2).

41BW2-3A. The section has a greenish-gray paste, black in xpl, isotropic, dense and silty. The section has a very small proportion of plutonic quartz. Its minor minerals are hematite, muscovite, and a significant proportion of clay balls. Particle Diversity 7. 
41BW2-1A. The section has a reddish-brown matrix, isotropic, and dark gray in xpl. It contains minor amounts of tempering quartz and some pieces of Rock A. Hematite is found in large amounts, and other minor minerals include muscovite. Bioclasts include bone and one piece of shell, the only shell bioclast in the entire paste group. Particle Diversity 11.

41BW2-7A. The section has a dense, dark reddish matrix, black in xpl, and isotropic. The matrix is exceptionally dense and silty. The section seems to lack any candidate for temper. Minor minerals are hematite and clay balls. One piece of bioclastic bone was found in the section. Particle Diversity 7.

41BW2-11A. The matrix is dense, silty, very dark brown, isotropic, and black in xpl. The tempering agent is quartz in its combined plutonic, sheared, and chert forms. Hematite is the minor mineral. The section also contains bioclastic bone. Particle Diversity 8.

41BW2-13A. The matrix is dense, isotropic, silty, dark reddish-brown, and black in xpl. The section seems to lack a tempering agent, having only a trace of chert as an aplastic inclusion larger than any of the abundant silt particles that would serve. Clay balls are abundant, however, and minor minerals are muscovite and hematite. Particle Diversity 6.

41BW2-6A var. 1. The section has a moderate, silty, medium reddish-brown anisotropic matrix, gold to black in xpl. This is the principal variety of the paste group. It contains hematite and clay balls in abundance as minor minerals and a smaller proportion of muscovite. Rock D, ilmenite, has a proportion of 3.5 percent. The section has bioclastic bone and a bioclastic insect egg case. Particle Diversity 10.

41BW2-5A var.1. The section has a dense, silty, medium reddish-brown anisotropic matrix, gold to black in xpl. The tempering agent is quartz in sufficient proportion for vessel manufacture. Hematite is the major additional mineral, and there are small amounts of muscovite and clay balls. A small proportion of bioclastic bone is also found in the section. Particle Diversity 8 .

41BW2-8A var. 1. The section has a dense, silty, medium reddish-brown anisotropic matrix, gold to black in xpl. It is also tempered with a small amount of quartz, and otherwise has a large proportion of hematite and a small amount of muscovite. Rock D fragments are notable in the section, but it lacks any bioclasts. Particle Diversity 9.

41BW2-21A var. 2. The matrix is silty, medium brown, moderate and isotropic. It is black in xpl. The matrix is tempered with quartz and otherwise has a large amount of clay balls and hematite and a small amount of muscovite. It lacks bioclasts or rock fragments. Particle Diversity 8.

41BW2-14A var. 2. The matrix is extremely silty, isotropic, moderate, medium brown in ppl and golden brown in xpl. Hematite is the most abundant aplastic inclusion but it is unlikely to be the tempering agent because it is too soft. Quartz other than silt is in minor proportion. Muscovite and clay balls are the minor minerals, and the section has one bioclast in the form of an insect egg case. Particle Diversity 8.

\section{Paste Group I}

41BW2-2A

The paste group has one member, 41BW2-2A, and is a grog-tempered group. The matrix is moderate, silty, dark, and isotropic. It is dark brown in ppl and dark grayish-gold in xpl. It contains much hematite, clay balls, and muscovite. The section also contains Rock $\mathrm{A}$ and Rock $\mathrm{C}$ in minor amounts. The section has one fine sandsized rounded piece of bioclastic shell. The section and paste group are very similar to grog-tempered Paste Group B at the Hickory Hill site in Camp County (Robinson et al. 2012). Particle Diversity 11. 


\section{Paste Group J}

41BW2-4A

41BW2-10A

41BW5-1A

41BW2-16A var. 1

Paste Group $\mathrm{J}$ is a shell-tempered group. The paste is moderate and silty, although in varying amounts; the silt is not consistent enough to suggest acquisition from a single clay resource locality. The shell tempering in every case ranges widely in size, from coarse silt to coarse sand and even granule in one case (41BW2-4A). Hematite and clay balls are common in the sections of the group. The group has one variety.

Shell tempered pottery is uncommon in this part of the Texas Red River Caddo region, although it was extensively made by the McCurtain phase Caddo peoples upstream on the Red River after ca. A.D. 1300 (Perttula 2013) and by the post-A.D. 1500 Belcher phase Caddo peoples living in Southwest Arkansas and Northwest Louisiana. At the Eli Moores site, 5.7 percent of the plain ware, fine ware, and utility ware sherds in the TARL collection are from shell-tempered vessels (Perttula 2015:Table 2). The distinctiveness of shell temper in the group strongly suggests extra-regional sources for the pottery, most likely from contemporaneous Belcher phase groups. Section 41BW2-16A with its carbonates in addition to shell is certainly of non-local manufacture.

41BW2-4A. The section has a dense, silty, anisotropic matrix yellow-brown in ppl and ranging from gold to gray in xpl. The shell temper is in a huge proportion (35.5 percent). The longest plates of the shell arc in the shape of a mussel valve, although this observation may be more impressionistic than real. The section has much hematite and clay balls and otherwise small amounts of quartz and muscovite. It contains a trace of Rock A. Particle Diversity 9.

41BW2-10A. The section has a moderate, isotropic, and silty dark brown (ppl) paste that is black in xpl. Voids are irregular and unoriented. Additional particles are clay balls and hematite. Particle Diversity 5.

41BW5-1A. As mentioned above, the Roseborough Lake site (41BW5) lies only a few miles upstream from the Eli Moores site (41BW2), and section 41BW5-1A clearly belongs to shell-tempered Paste Group J. The paste is dense, isotropic, and silty, dark gray in ppl and black in xpl. The sherd is heavily shell-tempered and also has copious hematite and clay balls. Non-silty quartz is found in small quantities, and muscovite is the only other minor mineral. The section lacks any bioclasts. Particle Diversity 8 .

41BW2-16A var. 1. The matrix is a moderate, isotropic, silty paste medium brown in ppl and dark reddish-brown in xpl. It also has very few silt-sized, irregular voids. Shell temper is in large amounts in the section, followed by clay balls and hematite. The section stands out, however, by having a sprinkling of carbonates through it, including dolomite, calcite, and a trace of limestone. The section also has a few pieces of bioclastic bone. The section is from a non-local ceramic vessel.

This sherd and the ceramic vessel to which it belonged are very likely to have been transported to the Bowie County site area, perhaps from a Caddo group living downstream from the Eli Moores site. This is by reason of both the shell tempering and the carbonates, both of which are uncommon in the local ceramics (but note: minor outcrops of limestone exist in geologic formations in the region; their proximity to the subject sites is unknown). Particle Diversity 10. 


\section{Paste Group $\mathrm{K}$}

41BW2-15A

41BW2-19A

41BW2-20A

Paste Group K is a small group with moderate pastes and variable although generally light colors and varying isotropy. Quartz is the temper, varying in quantities but generally in large amounts, and silt is minor. Hematite and clay balls are common, but they, too, vary in their proportions. Of the three sections in the group, only 41BW2-20A has muscovite.

41BW2-15A. The matrix is dark gray to black in ppl, very dark gray in $\mathrm{xpl}$, and isotropic. The matrix is also moderate with numerous irregular, unoriented voids. The section is tempered with crushed plutonic quartz, and otherwise hematite and clay balls are very common. A trace of Rock D was also observed. Particle Diversity 6.

41BW2-19A. The section has a quartz-tempered, non-silty, anisotropic paste. Colors are light tan and golden in ppl and golden to reddish-brown in xpl. Voids are long strips and irregular shapes that do not outline solid particles. Quartz is abundant, as are hematite and clay balls. The section lacks bioclasts or rock fragments. Particle Diversity 8.

41BW2-20A. The section is light and medium brown in ppl and gold to reddish-brown in xpl. It is quartz-tempered, anisotropic and moderate, with voids in irregular strips and ovals, unoriented. Quartz was common in a variety of forms, and hematite and clay balls are abundant. Muscovite is a minor mineral. A Rock A fragment and a bioclastic shell fragment were each observed in different clay balls. Particle Diversity 9.

\section{Paste Group L}

41BW2-9A

The paste group has one member in it, 41BW2-9A. The group and section are highly distinctive for having a small suite of carbonate rocks and minerals. The section is otherwise a dense, variable, anisotropic and silty section with colors ranging from medium brown in ppl and gold to gray in xpl. Voids are long, jagged strips that are unoriented and do not surround, or outline, solid particles. Quartz and the carbonates are the likely tempering materials, and hematite and clay balls are very common. Carbonates vary from minor to significant proportions and include dolomite, calcite, oolitic limestone, dolomitic limestone, and limestone. The strength of this carbonate contribution compared to the rarity of carbonates in local ceramics is impressive and suggests strongly a non-local origin for the ceramic vessel. It should be noted that the nearby outcropping Midway group, undivided, has scattered minor outcrops of limestone (Flawn 1979). The distances from the site of these potential outcrops are unknown. This evidence of non-local origins compares similarly with shell-tempered Paste Group J and its variant section 41BW2-16A, which also contains carbonates. Particle Diversity 12.

\section{Alligator Pond Site (41SM442)}

The Alligator Pond site is a substantial multi-component prehistoric and historic archaeological site (ca. 1.5 acres) on an upland ridge on the east side of Saline Creek. Saline Creek is a northward-flowing tributary to the Sabine River, and the site is ca. $10 \mathrm{~km}$ south of the confluence of Saline Creek with the Sabine River, in the Post Oak Savannah in northern Smith County, Texas. 
Previous analyses of the artifact assemblages indicates that the principal component is a pre-A.D. 1200 Caddo habitation site, from which the sherds submitted for petrographic analysis mainly derive, although the few brushed sherds in the assemblage also suggests the site was settled by Caddo peoples after ca. A.D. 1200. There is also evidence from temporally diagnostic ceramic sherds and dart points that the site was used to some extent during the Woodland (ca. 500 B.C.-A.D. 800), Late Archaic (ca. 3000-500 B.C.), and Middle Archaic (ca. 6000-3000 B.C.) periods (Perttula and Thacker 2013, 2014; Perttula and Walters 2012).

A total of 22 sherds were submitted for petrographic analysis from the Alligator Pond ceramic assemblage. The sherds are from plain wares $(\mathrm{n}=2)$, a red-slipped vessel $(\mathrm{n}=1)$, and brushed, incised, incised-punctated, and punctated utility ware vessels $(\mathrm{n}=19)$ (Table 4).

Table 4. Descriptions of the sherds submitted for petrographic analysis from the Alligator Pond site (41SM442).

\begin{tabular}{lll}
\hline Sherd No. & Description & $\begin{array}{l}\text { Figure Ref. (Perttula and } \\
\text { Thacker 2013) }\end{array}$ \\
\hline 41 SM442-1 & plain rim-flat lip & Figure 12d \\
p1SM442-2 & int./ext. red-slipped rim & Figure 12f \\
41 SM442-3 & brushed body sherd & Figure 18a \\
41 SM442-4 & brushed body sherd & Figure 15a \\
41 SM442-5 & brushed body sherd & Figure 15b \\
41 SM442-6 & incised-punctated rim sherd & Figure 15c \\
41 SM442-7 & incised-punctated rim sherd & Figure 16c \\
41 SM442-8 & incised body sherd & Figure 16b \\
41 SM442-9 & incised rim sherd & Figure 16a \\
41 SM442-10 & incised rim sherd & Figure 13b \\
41 SM442-11 & incised rim sherd & Figure 13a \\
41 SM442-12 & incised body sherd & Figure 13d \\
41 SM442-13 & incised body sherd & Figure 13g \\
41 SM442-14 & incised body sherd & Figure 13c \\
41 SM442-15 & incised body sherd & Figure 13f \\
41 SM442-16 & punctated rim sherd & Figure 13e \\
41 SM442-17 & punctated body sherd & Figure 14d \\
41 SM442-18 & punctated body sherd & Figure 14c \\
41 SM442-19 & punctated body sherd & Figure 14g \\
41 SM442-20 & punctated body sherd & Figure 14f \\
41 SM442-21 & punctated body sherd & Figure 14e \\
41 SM442-22 & & Figure 14b \\
\hline
\end{tabular}

\section{Paste Group M}

41SM442-21

41SM442-20

41SM442-18

41SM442-9

41SM442-8

41SM442-13

41SM442-2

The paste group is the largest of the site sample, with seven members. All the pastes are anisotropic and 
silty, moderate and dense, with colors in the yellow and brown ranges in ppl and golden to dark brown and black in xpl. Muscovite is found in every section as it has ubiquity in the site sample. The paste group is internally consistent, and no varieties were defined for it. The paste pattern is the typical and modal paste at the Alligator Pond site (41SM442).

41SM442-21. The matrix is moderate, silty, anisotropic and yellow-brown in ppl, gold to black in xpl. Voids are unoriented ovals that do not surround particles. Several forms of quartz comprise the tempering agent, and hematite is the next most frequent body in the matrix. Clay balls and muscovite are the minor minerals. A trace of Rock A was observed in the section. Particle Diversity 9.

41SM442-20. The matrix is moderate, silty, anisotropic, medium yellow-brown in ppl and gold to dark brown in xpl. Voids are parallel wavy strips that outline particles occasionally. Several forms of quartz comprise the tempering agent, and hematite is the next most abundant mineral in the section. Muscovite and a few particles of clay balls are the minor minerals. One particle of Rock $\mathrm{C}$ was observed, as was one small piece of bioclastic bone. Particle Diversity 9.

41SM442-18. The matrix is medium yellow-brown in $\mathrm{ppl}$ and gold to black in $\mathrm{xpl}$ and anisotropic. It is silty and dense, with sub-parallel voids in strips and oval shapes. The temper is quartz, and muscovite, hematite, and clay balls are the minor minerals. Two clear particles of grog were observed, but in such incidental amounts they could not have been the temper. Particle Diversity 9.

41SM442-9. The section has a dense, silty, anisotropic matrix light tan-brown in ppl and brown to gold in xpl. Voids are irregular and unoriented. The section is quartz-tempered, and has abundant hematite and lesser amounts of muscovite and clay balls. Two particles of chlorite (another form of mica) were observed along with three particles of Rock C. Particle Diversity 10.

41SM442-8. The section has a dense, silty, anisotropic and variable matrix, light tan-brown in ppl and brown to gold in xpl. A very small amount of quartz (plutonic, sheared, and chert) may have tempered the section. Hematite is found in much higher proportion (18 percent) than the quartz forms, but hematite masses and particles are probably too soft and malleable to buffer thermal shock in the clay mass. Silt-sized muscovite is the principal minor mineral in the section, and particles of Rock A and chlorite were also observed. Particle Diversity 10.

41SM442-13. The section has a moderate, variable, silty, anisotropic matrix colored yellow-brown in $\mathrm{ppl}$ and varying from gray to gold in xpl. Voids are irregular wavy strips that outline solid particles. The section is tempered with quartz in generous proportions, and minor minerals are hematite, muscovite, and three particles of Rock B. Two particles of bioclastic bone were also noted. Particle Diversity 10.

41SM442-2. The section has a dense, silty, anisotropic and variable matrix yellowish tan in ppl and gold to black in xpl. Voids are wavy strips and ovals. The section may have been tempered with a small amount of quartz. Minor minerals are hematite and muscovite. One piece of bioclastic shell was also observed. Particle Diversity 8 .

\section{Paste Group N}

41SM442-5

41SM442-7

41SM442-14

41SM442-22

The paste group is marked by diversity, with generally high particle diversity indexes, suites of minor minerals, and sprinklings of bioclasts. Pastes are silty, isotropic or anisotropic, and colors range from red to 
brown in ppl to gold and black in xpl. The tempering material is varying amounts of quartz. Small amounts of rock fragment types B, C, and D are found in the group.

41SM442-5. The matrix is moderate, silty, variable, and isotropic. The color in ppl is a medium redbrown; it is black in xpl. Voids are plentiful unoriented wavy strips and ovals. The temper is quartz, and minor minerals are hematite and muscovite. Rock $\mathrm{C}$ was observed in the section. Bone and shell bioclasts were also found in the section. Particle Diversity 12

41SM442-7. The section has a thin, silty, isotropic matrix reddish-black in ppl and black in xpl. Voids are irregular wavy strips and ovals in sub-parallel alignment. The temper is quartz, and other common minerals are hematite, muscovite, and clay balls. A minor mineral is chlorite. Rocks C and D were also observed in the section, and it contained one piece of bioclastic bone. Particle Diversity 11.

41SM442-14. The section has a thin, variable, silty, anisotropic section. Its colors vary from light tan and reddish-brown in ppl to gold and black in xpl. Voids are unoriented strips and irregular shapes that surround larger particles. Quartz is the temper, and hematite and clay balls are other mineral components. The principal minor mineral is muscovite, and individual grains of biotite and feldspar were also observed. A trace of hornblende was noted. Rock B was also found in the section. Particle Diversity 11.

41SM442-22. The matrix is moderate, silty, and isotropic. The color is medium brown in ppl and black in xpl. The temper is quartz, and hematite and clay balls are other abundant minerals. A trace of grog was observed in the section. Minor minerals are muscovite, chlorite, and hornblende. One piece of bioclastic bone was observed. Particle Diversity 11.

\section{Paste Group $O$}

41SM442-1

41SM442-10

41SM442-6

41SM442-12

41SM442-15

41SM442-11

The paste group is the bone-tempered group at the Alligator Pond site (41SM442), comprised of six members. All the pastes are isotropic, reddish-brown in plane-polarized light and black in cross-polarized light. Silt in the pastes is variable from low to moderate. Non-silty forms of quartz are generally low in the group, as are clay balls and hematite. Examples of Rock C were found in four sections, and Rocks B and D in one each. As usual in the Smith County collections, muscovite was found in every section.

41SM442-1. The section matrix is thin and black in both lights. Voids are wide, strip-like and unoriented. Bone tempering is copious, and quartz and clay balls are abundant. Minor minerals are hematite and muscovite. Rock C was observed in the section. Particle Diversity 9.

41SM442-10. The matrix is moderate, non-silty, isotropic, and red-brown in ppl and black in xpl. Voids are irregular and unoriented. Quartz may have had tempering effects in addition to the small proportion of bone. Minor minerals are hematite, clay balls, biotite, and muscovite. Both Rock C and Rock D were observed in the section. Particle Diversity 12.

41SM442-6. The matrix is thin, non-silty, isotropic, medium brown in ppl and black in xpl. Voids are unoriented strips and ovals. It is copiously tempered with bone particles. Minor minerals are quartz, hematite, clay balls, hornblende and muscovite. Rock $\mathrm{C}$ was found in the section as was a trace of bioclastic charcoal. Particle Diversity 11. 
41SM442-12. The matrix is moderate, isotropic, silty, and reddish-brown in ppl and dark gray brown in xpl. Voids are wavy strips and ovals. The section is copiously tempered with bone, and also has quartz, clay balls, hematite, muscovite, and at least two particles of Rock C. Particle Diversity 10.

41SM442-15. The matrix is moderate with comparatively low silt and copious bone temper; the ceramic fabric is isotropic, reddish-brown in ppl, and black in xpl. Voids are irregular and unoriented. The section has a large proportion of clay balls. Minor minerals are quartz, hematite, biotite, and muscovite. Particle Diversity 9.

41SM442-11. The matrix is moderate, isotropic, moderately silty, and is gray-brown in ppl and black in xpl. Voids are wavy strips and irregular shapes, all unoriented. There is a relatively modest amount of bone temper. Hematite is found in relatively large proportions. Minor minerals include quartz in several forms, clay balls, muscovite, and hornblende. Several particles of Rock B were found in the section. Particle Diversity 13.

\section{Paste Group P}

41SM442-3

41SM442-4

41SM442-16

41SM442-17 var. 1

41SM442-19 var. 1

The paste group is one of variable, generally dark colors, dense and non-silty. The group is generally anisotropic, but variety 1 is isotropic, and the matrix colors are much darker. The group is tempered with various forms of quartz.

41SM442-3. The paste is moderate, anisotropic, variable and medium brown in ppl and gold to black in $\mathrm{xpl}$. Voids are sub-parallel strips and ovals. The temper is quartz, and minor minerals are hematite, muscovite, and clay balls. Rock C was identified in the section. Particle Diversity 10.

41SM442-4. The section is moderate, variable, non-silty, anisotropic, and colors are medium brown in $\mathrm{ppl}$ and gold to black in xpl. Voids are wavy strips up to coarse sand sizes in length. The section is copiously tempered with quartz in grain sizes up to medium sand. The most common additional particle is hematite. Other minor minerals include muscovite, clay balls, and alkali feldspar. Several particles of Rock C were observed in the section. One particle of bioclastic shell was also observed. Particle Diversity 12.

41SM442-16. The matrix is moderate, anisotropic, and variable with a reddish-brown color in ppl and colors varying from dark reddish-gray to dark golden and gray in xpl. Voids are large, unoriented, and irregular; they outline the larger solid particles. The section is well tempered with quartz up to medium sand sizes. The section also has generous amounts of clay balls and hematite. The minor mineral is muscovite in medium silt and coarse silt sizes. A small proportion of bone in fine sand sizes is bioclastic, too minor to have served as a deliberately added temper. Particle Diversity 10.

41SM442-17 var. 1. This section and 41SM442-19 are defined as a variety of Paste Group P because they are both isotropic pastes that are almost uniformly black in ppl and $\mathrm{xpl}$ and have low to moderate silt. Voids are few and irregular. This section is copiously tempered with quartz, but has few other particles. Hematite is the most abundant minor mineral, followed by muscovite and one observed particle of limestone. Particle Diversity 9

41SM442-19 var. 1. As mentioned above, the section is isotropic and is almost uniformly black in both lights except for minor areas of dark reddish-brown in ppl. Voids in this section are sub-parallel strips 
and ovals. The section is tempered with quartz, and clay balls and hematite are common additional aplastic inclusions. Minor minerals are muscovite and biotite, and the section contains a minor fraction of bioclastic bone. The clay balls may be non-local material or they may include material from different sources or localities, as they are lighter in color than the rest of the matrix. Also, a particle of plagioclase feldspar and another piece of bioclastic bone were observed in the clay balls (particle clasts in larger particles are not tabulated separately on the counting sheet; they are noted, when observed, in the notes section). Particle Diversity 10.

The Variety 1 sections of Paste Group P, 41SM442-17 and 41SM442-19, are strikingly similar to Paste Group J at the Hickory Hill site (Robinson et al. 2012). There, Paste Group J is comprised of a single section, CP408-627.1. It is also noted as being a non-local paste group at the site (Robinson et al. 2012).

\section{Geology and Source localities}

\section{Shelby Mound (41CP71)}

The Shelby site (41CP71) sits alongside Greasy Creek in the Big Cypress Creek drainage in Camp County. The immediate setting is Quaternary alluvium or floodplain deposits. The site may also overlie material of the Eocene Queen City Sand. The formation is described in part as one of quartz sand with thin beds of clay and sandy clay and ironstone concretions. Throughout the formation, quartz sands, clay beds, and sandy clay beds alternate in various combinations (Flawn 1975). Here are common and widespread sources for ceramic materials. The formation contains recoverable amounts of Ilmenite (Shelby and Fisher 1965: 200).

The site also lies within a mile of outcrops of the Eocene Weches formation, described as glauconitic, with quartz sand and clay interbeds, and "clay, silty, muscovitic,"... and "locally forms limonitic and sideritic iron ore (Flawn 1975)." The Weches and the Reklaw formations are sources for the muscovite for which Camp County Caddo ceramics are well noted (Robinson et al. 2012). Alluvial and residual clay beds may lie within easy reach of the Shelby Mound site.

\section{Eli Moores (41BW2) and Roseborough Lake (41BW5)}

The two Bowie County sites lie on floodplain deposits of the Red River a few miles west of Texarkana. At the Eli Moores site (41BW2), deposits are mostly sand, silt, and some clay, and these are red to tan in color. Approximately one mile south of the site lie deposits of the Eocene Midway group; they are undivided between the Wills Point and Kincaid formations. The Wills Point is mostly clay and some silt in the upper part, with some calcareous siltstone concretions, a "thin bed of rosette limestone (Flawn 1979)" near the middle and glauconitic in the lower part. The Kincaid is also mostly clay, which is calcareous, glauconitic, or selenitic. It may also have silty and sandy areas and some thin beds of hard, gray limestone. At the Roseborough Lake site (41BW5), the alluvial deposits are said to be sand, silt, and some clay, red to tan in color and surface scrolled (Flawn 1979).

\section{Alligator Pond (41SM442)}

The Alligator Pond site (41SM442) lies alongside Saline Creek, a minor tributary of the Sabine River in Smith County. The site rests on alluvial deposits of the creek, and the stream is flanked on both sides of its narrow floodplain by outcrops of the Queen City Sand, with its quartz sand and thin beds of clay and sandy clay (Flawn 1975). Again, the ancient potters may have had numerous choices among suitable alluvial and residual clay resource localities. 


\section{General Observations}

The sample ceramics from the Shelby Mound site have varying pastes, textures, and materials. They were divided among six paste groups. Paste groups B and E have varieties. Paste Group E is also the bonetempered group. Paste Group C is grog-tempered but only had two sections, and they had dissimilar grog types within them; otherwise, the paste group has a high degree of internal consistency. Across the paste groups, clay balls varied from 10.5 percent to being entirely absent from four sections. Similarly, muscovite varied from 8.5 percent to absence in five sections, including absence in all three sections of Paste Group A; and hematite varied from 30.5 percent (in Paste Group F, the likely non-local paste group) to complete absence in one section. Rock D, ilmenite, is found in three paste groups: C, E, and F. Ilmenite is found notably in the Queen City Sand, local to the Shelby Mound area (Shelby and Fisher 1965:200). The decorative styles on the utility ware and fine ware sherds from the Shelby Mound site submitted for petrographic analysis (see Table 1) are consistent with the broad range of decorated ceramics in the assemblage (see Perttula 2014), and none appear on stylistic grounds to be from non-locally produced ceramic vessels. Paste Groups A-E sherds are both from fine ware and utility ware vessels, and only Paste Group F is represented by just utility wares. The six paste groups in the ceramic assemblage suggest there was a considerable range in clay sources and paste recipes employed by the Caddo potters living at the Shelby Mound site.

The Bowie County sites have six paste groups, and the single section from the Roseborough Lake site fits well in Paste Group J in the Eli Moores site sherd samples. Paste Group I is a grog-tempered paste group with a single section, 41BW2-2A. Paste group J is a shell-tempered group with one variety, 41BW2-16A. Its significant variation is in having several carbonates as minor minerals and a lack of micas. Shell temper is relatively rare in this part of the Red River basin in Northeast Texas, and the entire paste group may be non-local. Across all the paste groups, hematite is present in all the sections, varying from 4-24.5 percent. Muscovite, however, is only sparsely represented, from 9 percent to complete absence in seven sections out of the total of 22 sections. Other micas are absent from the sites' paste groups. The paste group with 9 percent muscovite is Paste Group I, the only paste group that is grog-tempered. The local geological formations, the Midway Group undivided and the Wilcox Group, are not described as having muscovite (Flawn 1979). Muscovite is much more available in Camp County, Smith County, and Rusk County to the southwest of Bowie County and the Red River. Paste Group I is also suggested to be from a non-local source. Based on ceramic styles in the fine ware and utility ware sherds submitted for petrographic analysis (see Table 2), the sherds from Paste Groups G, H, and K are from vessels made locally, while the ceramic styles in the other paste groups (I, J, and L) are suggestive of vessels made by non-local Caddo potters. In Paste Group I is a Belcher Ridged jar sherd, pointing to a Belcher phase-Northwest Louisiana provenience; Paste Group $L$ is a red-slipped vessel. The source of this vessel may be one of several Northeast Texas areas where Caddo potters made red-slipped vessels in post-A.D. 1430 times, including the upper Sabine and mid- and upper Big Cypress Creek basins. The shell-tempered Simms Engraved and brushed ceramics in Paste Group $\mathrm{J}$ at the Eli Moores site likely were made by Belcher or post-A.D. 1680 Chakanina phase Caddo potters living along the Red River in Southwest Arkansas and Northwest Louisiana.

The Alligator Pond thin sections all contain muscovite, in proportions ranging from $0.5-8.5$ percent. Other micas including biotite and chlorite are found occasionally in trace amounts. Several branches of Saline Creek drain the muscovitic Weches formation that outcrops widely in Smith County (Flawn 1975), so its abundance is well represented in the locally made ceramics. The pastes also have sprinklings of all the rock types identified in this study. Two sections have grog in trace amounts, but grog temper did not define any paste group or variety. The most typical paste in the sample is Paste Group M, which has anisotropic light yellowish-brown moderate and dense silty pastes. Paste Group $\mathrm{O}$ is a strongly bone-tempered group. The site collection lacked any shelltempered sections, but two sections, 41SM442-4 and 41SM442-5 have bioclastic shell. The decorative styles on the plain ware, utility ware, and fine ware sherds from the Alligator Pond site that have been submitted for petrographic analysis (see Table 4) are consistent with the broad range of decorated ceramics in the assemblage (see Perttula and Thacker 2013), and none appear on stylistic grounds to be from non-locally produced ceramic vessels. All recognized paste groups are represented in the utility wares. 
Rock C is found relatively often in the Alligator Pond pastes. It is found in all four of the site's paste groups, in 10 of the individual sections. The rock appears to be a siltstone, and all the nearby formations have silt. But any described siltstone is more than 10 miles to the west (Flawn 1975). The source for the siltstone remains unknown.

\section{Isotropy, clay beds, and bioclasts}

Isotropy, or the quality of isotropism, refers to the general state of light transmission through any crystalline material. The term isotropic means that light is transmitted through the material in the same way at all angles and orientations to the light. The term anisotropic means that light is not transmitted equally in all orientations. In practical optical mineralogy with the petrographic microscope, this distinction means that isotropic bodies are extinct, or black, when viewed in cross-polarized light (xpl). Anisotropic materials affect, or distort, the light in a regular way between the polarizers, and so some of the light is transmitted through the crossed polarizer.

This distinction is very broad, and may have many causes in any case. In the field of clay mineralogy, this also holds true, and any isotropic state may have many explanations. But, broadly considered, this may mean that clay masses of unitary mineralogy will have the same isotropy, either isotropic or anisotropic. This is more likely to be the case in residual clay beds where one or a few clay minerals develop over time under the decomposition of a parent rock. Clays of several mixed mineralogies, however, are most likely to be anisotropic rather than isotropic. And these mixed clays are more likely to be encountered in alluvial beds, where many clay mineral masses may be deposited by stream action and reside together.

This tentative hypothesis may be posited for the clay matrixes in the current study collection. By this hypothesis (repeating that there may be several explanations for any given state) the isotropic pastes may be more likely to have originated in residual beds, and anisotropic pastes may more likely have originated in alluvial beds. Reviewing the cases may call for confirmatory evidence. The hypothetical origin of bioclastic shell in alluvial beds may point in this direction. If bioclastic shell and anisotropic pastes co-occur in pastes significantly, then the ceramics may have been built from alluvial clays. Table 5 gives the isotropic state of matrixes that also contained bioclastic shell.

Table 5. Isotropy in petrographic sherd samples from the Eli Moores (41BW2) and Alligator Pond (41SM442) sites.

\begin{tabular}{llll}
\hline Site & Paste Group & Isotropy & Shell Percent \\
\hline 41 BW2 & G & Iso & 1 \\
& G & Iso & Tr. \\
& H & Iso & 0.5 \\
I & Iso & 0.5 \\
41 SM442 & & & \\
& M & Aniso & 0.5 \\
& $\mathrm{~N}$ & Iso & 1 \\
& $\mathrm{P}$ & Aniso & 0.5 \\
\hline
\end{tabular}

Identified bioclastic shell was lacking in the Shelby Mound (41CP71) collection. Table 5 shows clearly by inspection that bioclastic shell is more significantly associated with isotropic pastes than with anisotropic ones. The hypothesis that there is a meaningful association between bioclastic shell and paste isotropism is falsified, and we cannot currently infer possible ecological settings of clay resource localities from these data. The premises are likely too tentative to apply in a small scale collection such as this one, and other compelling variables are also at work, likely the mixing of materials in clay manufacture, the obscuring effects of carbon, and, of course, post-depositional processes. 


\section{Intersite Comparisons}

The three site areas have their own common pastes and distinctive variations within them. The Shelby Mound ceramics have common greenish-gray dense pastes. The Bowie County sites have reddish-brown pastes with rough or tumbled looking textures. The Alligator Pond site ceramics have a distinctive yellow or yellow-brown paste typified by Paste Group M. These pastes show their local distinctions, and at the same time, all three areas have dark pastes, which may relate more to carbon content and firing technology than to resource localities. Silt content varies widely in all areas. Of the three site areas, only the Bowie County sites have a shell-tempered paste group, J, and it is shared between the two nearby sites. Other similarities between the three site areas are few, but they are suggestive.

Grog-tempered pastes $\mathrm{C}$ at the Shelby Mound site and I at the Eli Moores site are small grog-tempered paste groups. Beyond their grog, however, they share little in paste characteristics of additional minerals. Grog temper is incidental at the Alligator Pond site.

Bone-tempered wares have a few closer connections. Bone-tempered sections 41CP71-14A and 41CP7115A belong to Paste Group E. They could easily be added to Paste Group O (bone-tempered) at the Alligator Pond site. The similarities are strong enough to suggest transport or trade, although the two sites are several hundred years apart in age, and post-A.D. 1450 Caddo occupation of the Saline Creek area was negligible.

Comparing to other studies, paste groups A and B at the Hickory Hill site in Camp County (Robinson et al. 2012) have the Camp County local look of greenish-gray anisotropic pastes that are silty and have significant muscovite. They also have clay balls, a few mixed grog particles, and highly variable amounts of hematite. These sections could be interchangeable with Paste Group A and to a lesser extent Paste Group B at the Shelby Mound site. The same letter designations are by analytic chance. The similarities are petrographic. Furthermore, Paste Group M at the Hickory Hill site is a dark, silty isotropic bone-tempered group which could be interchangeable with varieties 1 and 2 of bone-tempered Paste Group E at the Shelby Mound site.

Paste Groups E and F at 41SM404 (Robinson 2012) are bone-tempered and have significant similarities with Paste Group $\mathrm{O}$ at the Alligator Pond site, although the sites are in different stream basins. The similarities include low silt counts, variable clay balls and hematite, as well as trace contributions of volcanics and one piece of bioclastic shell. Interestingly, a specimen described as Unknown B in that study for 41SM404 is similar to this study's Rock C, a possible siltstone, found in low, intermittent proportions in both studies.

Rusk County and the Musgano site (41RK19) lie to the southeast of Smith County, farther downstream in the Sabine River drainage. Petrography by Tomka et al. (2015) offers comparisons with a critical region. The petrography of 20 sherds from the Musgano site showed a much greater concern with bone tempering than in the samples discussed herein from Smith and Camp counties. In congruence with the Alligator Pond site, many sections had bone particles in their clay balls and grog. Other sections contained grog and clay balls of materials significantly different from the larger matrix. The local clays also contain traces of alkali feldspar, hornblende, and other igneous minerals. Exact comparisons are hampered by differences in presentation (temper groups versus paste groups), but these general comparisons nevertheless show similarities in technology and technique. Tomka et al. (2015:31) suggest that their own ceramic similarities lie farther to the east, in the middle drainage of the Sabine, where there are more heavily bone-tempered traditions. The Smith County and Camp County sites to the west show a lessening in that tradition with fewer bone-tempered paste groups and assemblages. Bowie County, far to the north on the Red River, shows a complete lack of the bone tempering tradition. 


\section{SPECIFIC SUMMARY OF LOCALITY AND CERAMIC SIMILARITIES}

The following list reports the paste groups and sections that appear to be non-local, or introduced to the sites in which they were found. The mechanisms of their transport to the sites remain to be determined by further archaeological research.

- Shelby Mound, Paste Group F, section 41CP71-11A

- Eli Moores and Roseborough Lake, Paste Group J, entire shell-tempered group, particularly section 41BW2-16A, var.1

- $\quad$ Eli Moores, Paste Group L, section 41BW2-9A

- $\quad$ Alligator Pond, Paste Group P, section 41SM442-19, var. 1

Additional inter-site comparisons reveal close similarities between and among paste groups and individual sections. They suggest various connections between the sites and are rightfully identified at this time. The cultural and technological mechanisms of their similarities may or may not be determinable affirmatively, and they await further research. Certainly the prospective INAA study of this collection will shed light on these issues.

- Shelby Mound, Paste Group E, section 41CP71-12A, var. 1 compares to Hickory Hill site (41CP408) Paste Group M.

- Shelby Mound, Paste Group E, section 41CP71-5A, var. 2 and section 41CP71-1A compare to Hickory Hill site, Paste Group L.

- $\quad$ Eli Moores, Paste Group I compares to Hickory Hill site, Paste Group B.

- Eli Moores, Paste Group G, section 41BW2-12A, var. 1 compares to Shelby Mound, Paste Group D.

- Alligator Pond, Paste Group P, sections 41SM442-17 var. 1 and 41SM442-19 var. 1 compare to Hickory Hill site, Paste Group J, section CP408-627.1.

- $\quad$ Shelby Mound, Paste Group E, sections 41CP71-14A and 41CP71-15A compare to Alligator Pond, Paste Group O.

Further research of all types will go far to clarify these relationships and identify others meaningful in Caddo prehistory. Additional study, sedimentological background work, and typological and geochemical characterizations hold promise in this research field.

\section{REFERENCES CITED}

Chayes, F.

1949 A Simple Point-Counter for Thin Section Analysis. American Mineralogist 34:1-11.

Flawn, P. T.

1975 Geologic Atlas of Texas: Tyler Sheet. Bureau of Economic Geology, The University of Texas at Austin.

1979 Geologic Atlas of Texas: Texarkana Sheet. Bureau of Economic Geology, The University of Texas at Austin.

Folk, R. L.

1980 Petrology of Sedimentary Rocks. Hemphill Publishing Company, Austin.

Gilmore, K.

1986 French-Indian Interaction at an Early Eighteenth Century Post: The Roseborough Lake Site, Bowie County, Texas. Contributions in Archaeology 3. Institute of Applied Sciences, North Texas State University, Denton. 
1991 An Archeological Footnote to History. Bulletin of the Texas Archeological Society 60:303-324.

Good, C.

1977 Moores Plantation: Thesis Prospectus. MS on file, TARL.

Jackson, A. T.

1932 Exploration of a Burial Site on E. H. Moores Plantation in Bowie County, Texas. MS on file, TARL.

Miroir, M. E., R. K. Harris, J. C. Blaine, and J. McVay

1973 Bernard de la Harpe and the Nassonite Post. Bulletin of the Texas Archeological Society 44:113-167.

Orton, C., P. Tyers, and A. Vince

1993 Pottery in Archaeology. Cambridge University Press, Cambridge.

Perttula, T. K.

2012 The Character of $15^{\text {th }}$ to $17^{\text {th }}$ Century Caddo Communities in the Big Cypress Creek Basin of Northeastern Texas. In The Archaeology of the Caddo, edited by T. K. Perttula and C. P. Walker, pp. 363-410. University of Nebraska Press, Lincoln.

2013 Caddo Ceramics in East Texas. Bulletin of the Texas Archeological Society 84:181-212.

2014 Caddo Ceramics from Mound Deposits at the Shelby Mound Site (41CP71) on Greasy Creek, Camp County, Texas. Journal of Northeast Texas Archaeology 46:7-43.

Perttula, T. K. (editor)

2015 The Eli Moores Site, a $17^{\text {th }}$ to early $18^{\text {th }}$ Century Caddo Site on the Red River, Bowie County, Texas. Special Publication No. 31. Friends of Northeast Texas Archaeology, Pittsburg and Austin.

Perttula, T. K. and B. Nelson

2004 Archeological Investigations at the Shelby Site (41CP71) on Greasy Creek, Camp County, Texas. Special Publication No. 5. Friends of Northeast Texas Archaeology, Pittsburg and Austin.

Perttula, T. K. and M. Thacker

2013 Analysis of New Artifact Collections from Archaic to Ancestral Caddo Sites in the Saline Creek Basin in Northern Smith County, Texas. Journal of Northeast Texas Archaeology 43:1-25.

2014 Additional Collections of Woodland to Caddo Period Artifacts from the Alligator Pond Site (41SM442), Smith County, Texas. Journal of Northeast Texas Archaeology 46:1-5.

Perttula, T. K. and M. Walters

2012 Caddo Sites in the Saline Creek Basin in Northern Smith County, Texas. Journal of Northeast Texas Archaeology 36:47-63.

Porter, J. W.

1971 Thin-Section Identifications of Spiro Sherds. In Spiro Studies, Volume 3: Pottery Vessels, by J. A. Brown, pp. 244-246. First Part of the Third Annual Report of Caddoan Archaeology—Spiro Focus Research. Stovall Museum of Science and History, University of Oklahoma and The University of Oklahoma Research Institute, Norman.

Reese-Taylor, K.

1993 Petrographic Analysis of Caddo Ceramics from Titus County, Northeast Texas. In Archaeological Investigations within the Monticello B-2 First Five Year Disturbance Area, Titus County, Texas, by S. M. Kotter, R. Rogers, R. Taylor, K. Reese-Taylor, and W. E. Glander, pp. A-1 to A-13. Document No. 920013. Espey, Huston \& Associates, Inc., Austin.

1994 Petrographic Analysis of Caddoan Ceramics from Rusk County, Texas. In National register Testing of Eight Archaeological Sites within the Oak Hill 2,280 Acre Study Area, Rusk County, Texas, by R. Rogers, E. Foster, and K. Reese-Taylor, pp. B-1 to B-15. Document No. 930169. Espey, Huston \& Associates, Inc., Austin. 
Rice, P. M.

1987 Pottery Analysis: A Sourcebook. University of Chicago Press, Chicago.

Robinson, D. G.

2012 Petrographic Analysis of Ceramic Sherds from 41SM404. In National Register of Historic Places Eligibility Testing of Site 41 SM404 within TxDOT's Tyler District, Smith County, Texas, by M. A. Nash, T. K. Perttula, and L. W. Ellis, pp. E-1 to E-13. Document No. 110055. Atkins, Austin.

2014 Geoarcheology and Ceramic Petrography: Summary and Prospectus for Ceramic Petrographic Research in Eastern Texas and Surrounding Regions. Paper presented at the $79^{\text {th }}$ Annual Meeting of the Society for American Archaeology, Austin, Texas, April 23 to 27, 2014.

Robinson, D. G., L. W. Ellis, and T. K. Perttula

2012 Technology and Learning: Caddo Ceramics from the Hickory Hill Site, 41CP408, Camp County, Northeast Texas. Paper presented at the 83rd Annual Meeting of the Texas Archeological Society, Tyler, Texas.

Shelby, C. A. and W. L. Fisher

1965 Heavy Minerals. In Rock and Mineral Resources of East Texas, edited by W. L. Fisher, pp. $200-204$. Report of Investigations 54. Bureau of Economic Geology, The University of Texas at Austin.

Shepard, A. O.

1942 Rio Grande Glaze Paint Ware: A Study Illustrating the Place of Ceramic Technological Analysis in Archaeological Research. Contributions to American Anthropology and History 7(9). Carnegie Institution of Washington, Washington, D.C.

1976 Ceramics for the Archeologist. 8th printing. Publication 609. Carnegie Institution of Washington, Washington, D.C.

Skokan-Switek, E.

1997 Results of the Petrographic Analysis of Ceramics from Site 41RK342, Rusk County, Texas. In Cultural Resources Investigations of the Oak Hill D-III Permit Area, Rusk County, Texas, by E. A. Skokan, E. Foster, and R. Rogers, Appendix E. Document No. 940002. Espey, Huston \& Associates, Inc., Austin.

Tomka, S. A., L. Barkwill-Love, and T. K. Perttula

2015 The Petrographic Analysis of Sherds from the Musgano Site (41RK19), Rusk County, Texas. Journal of Northeast Texas Archaeology 49:43-80.

Trubitt, M. B., T. K. Perttula, and R. Z. Selden Jr.

2014 Identifying Ceramic Exchange and Interaction between Cahokia and the Caddo Area. In Research, Preservation, Communication: Honoring Thomas J. Green on his Retirement from the Arkansas Archeological Survey, edited by M. B. Trubitt. Research Series, Arkansas Archeological Survey, Fayetteville, in press. 